International Journal of English Literature and Social Sciences
Vol-6, Issue-2; Mar-Apr, 2021
Journal Home Page Available: https://ijels.com/
Journal DOI: $10.22161 /$ ijels

\title{
Redefining Space in Eva Luna
}

\author{
Rekha E
}

Asst.Professor of English, Govt. College, Tripunithura, India

Received: 16 Dec 2020; Received in revised form: 25 Feb 2021; Accepted: 21 Mar 2021; Available online: 11 Apr 2021

(C)2021 The Author(s). Published by Infogain Publication. This is an open access article under the CC BY license

(https://creativecommons.org/licenses/by/4.0/).

\begin{abstract}
The existing power structures in society are based on regulatory principles that are slow to change. The oppressive system of gender that is in practice even today solicits responses that should pave the way for progressive changes in the ideas and concepts regarding women. Colonial rule sought to establish male hierarchy where power and authority were concerned and there was a corresponding lack of interest in providing due recognition to female power. The postcolonial discourse is engaged in listening to those voices that have been rendered feeble by the onslaught of colonialist enterprise and patriarchy. Recovering the long-lost spaces of the self is crucial in breaking down the wide gulf that separates the male and the female. Gender

assumptions that are held in high esteem lose their ground and egalitarian principles become widely acknowledged. This paper is a study of the novel Eva Luna by the Chilean-American writer, Isabel Allende and it analyses the spaces in which the protagonist finds herself, the negotiation of which enables her to confront truths and half-truths, leading to the emergence of her real self.
\end{abstract}

Keywords-Power, gender, postcolonial, spaces, egalitarian.

\section{INTRODUCTION}

Gender is a construct that is powerful in creating barriers and obstacles with relation to female positionality. Gender divide is obviously a process of segregation which is done by invoking the normative practices that a predominantly male society has created and which still endures in the modern era. The civilized world is witness to the various modes of

oppression, mainly gender repression, racism and imperialism. In the erstwhilecolonised countries the impact of colonisation is still felt to a certain extent. Writings from Latin Americadisplay a longing for the native traditions along with a desire to exist independently, breaking away frommalehegemony. But the striving for a proper cultural, national and even

personal identity is ambivalent in that the sense of such an identity cannot be extricated from what the coloniser has made the space out to be. Latin American culture and customs carve a strong identity that resists coloniality.

The postcolonial condition involves the negotiation of space which is multi-dimensional. A woman embarks on several journeys that enable her to identify her self and also comprehend her position as a subject in society. In particular, gender is a space that has allowed various pre-conceived notions to prevail. A woman is expected to comply with the

stereotypical notions that exist in society. In the novelEva Luna, the Chilean-American writerIsabel Allende uses the image of the titular characterto articulate the problems encountered by a woman in the spaces that she finds herself in.In a world that operates on male prerogatives, the female as both subject and object works within the parameters fixed by the society. This paper is an attempt to unravel the working of gender in a society that is biased and highlights the ambivalence in an identity that resists suppression.

The poststructuralist feminist critic Judith Butler locates the submissive position of woman in her unequal representation as the subject. In her influential work, Gender Trouble she says that the juridical formation oflanguage and politics is in itself discursive and the legitimisation of the laws that govern society exclude women from its purview. The 
mechanisms that dominate and render women as meek compel them to become victims of exploitation and oppression. The impact of colonisation on the female category of gender is stressed by OyeronkeOyewumi in the essay "Colonizing Bodies and Minds." "The emergence of women as an identifiable category, defined by their anatomy and subordinated

to men in all situations, resulted, in part, from the imposition of a patriarchal colonial state. For females, colonization was a twofold process of racial inferiorization and gender subordination." (The Post-Colonial Studies Reader 257) In the context of the Caribbean as well as that of Latin America, colonization served to suppress women in such a way that their respective cultures were never part of the civilizing mission. Gender can, in all aspects be regarded as part of the colonial project. The subjection of women was done quite naturally as it was universally assumed that they were inferior to men. Colonialism served to consolidate this misconception to such an unimaginable extent that the postcolonial concept of

nationhood is also unable to come to terms with the idea of female emancipation and selfhood. Womenare subjected to the status of objects who merely toe the line of the men of their community as well as the white masters. Personal identity is rooted in the perception of oneself. This identity is formed as a consequence of years of suppression, living in a nation. In the event of a change of circumstance, the conflict between the two worlds rages internally, the individual being unable to forget his/her past and come to terms with the present situation.

In the Latin American context the coloniality of gender works in ways that overarch the possibilities of reconciliation between the male and the female. There also arises the need to negotiate the position of the queer in the social, cultural, political and personal domains of life. Latin America is lush and beautiful in terms of scenic beauty and the social lives of the people are represented by the mechanics of power. Power relations which were once the

hallmark of the colonial periodretain their hold over the modern, independentnations and nowhere is this more evident than in the perpetuation of the gender system. It is with relation to one's gender that the forging of identity is spoken of. Representation of the female self

suggests the multidimensional aspects of a woman who can no longer be considered as just the other half of the male. Socially constructed half-truths about gender, race, class and ethnicity abound in spaces where selfhood is problematic.
In Eva Luna, Eva's whole life is accentuated by the reality of her being an orphan, but she is fortunate to meet a few human beings who help her in times of need. Hermadrina, Elvira,Huberto Naranjo and Rolf Carlé support her in the journeys that she undertakes but she is the one who manages her own life.Melesio, a transwoman also moves on in life and is

able to transform into a remarkable personality. "I am not homosexual, I am a woman. This body is a mistake. Nothing more, nothing less." (109)

Individual stories are connected with the turbulences that grip the nationwhich is an unnamed country in Latin America. A strong sense of uneasepervades the novel and it is further complicated by the emergence of a guerrilla group that is the outcome of resentment harboured against the military forces. It is the presence of dictators and men in power that is at the root of guerrilla uprising. Dissatisfaction coupled with despair triggers warfare and the dictatorial stand taken by the Government makes matters worse. Eva's personal life progresses steadily with changes in employment and her stints at various places sharpens her sensibility. It is her actual life experiences that teach her the lessons that noinstitution can impart.

The General who determines the rules for the entire nation before his dictatorship falls, relaxes immigration laws that makes it possible for refugees to arrivein large numbers. The contradictory nature of human import comes into focus here with the purpose of his

motivesremaining unclear.More than the General, it is the Chief of Political Police who exercises maximum control in the government. The ruthlessness with which the Military pursues potential targets, generates restlessness that projects itself as guerrilla warfare.

"While those in power stole without scruple, thieves by trade or necessity scarcely dared practice their profession: the eyes of the police were everywhere. That was the basis for the story that only a dictator could maintain order... The politicians of the opposition were in exile, but Elvira told me that in silence and shadow enough anger was brewing to cause the people to rebel against the regime." (69)

Eva's evolution is marked by her interaction with the diverse personalities who employ her as domestic help. Her stint at Riad Halabí' s house is crucial in helping her realise who she really is. The reality of her existence scares her forcing her to take refuge in an imaginative world. "In the motionless sands where my stories germinated, every birth, death, 
and happening depended on me. I could plant anything I wanted in those sands; I had only to speak the right word to give it life. At times I felt that the universe fabricated from the power of the imagination had stronger and more lasting contours than the blurred realm of the flesh-andblood creatures around me." (168) Eva decides to chart her own course after her arrest

as the prime suspect in the suicide of Zulema, Halabí's wife,by putting an end to the tediousness evoked by domestic chores once and for all. She would never work as a domestic help again. Thissets the stage for a new beginning, particularly in the wake of her reunion with Melesio, now known as Mimí,Huberto and Rolf Carlé.

Life with Mimí is easy for Eva because she is not used to the rigid positions taken up usually by society. This is so because of the harsh experiences of life actually lived by Eva. She is not conditioned by the socio-cultural constructs even though her madrinatries to bring herup in that way. She grows up as a free bird even though the basic conditions of her

existence do not allow her much freedom. Her real freedom lies in her strong and remarkable ability to make up stories, an art that she innately possesses, one that she clings to with passion and it is this spurt of creativity that comes to her rescue in hours of need. In the case of Eva the typical patterns of gender demarcation that persistently deny freedom to women are subverted.The legitimacy by which men regulate the lives of the female is disputed. According to the feminist theorist, Trinh T. Minh-ha, "A social regulator and a political potential for change, gender, in its own way, baffles definition." (Woman, Native, Other 116) Gender disparity is disavowed by Eva by and this is proved by her refusal to surrender to the whims of General Tolomeo Rodriguez who isclearly infatuated with her. Her conscience never defeats her and she remains true to her feelings towards each of her friendswhom she knows and understands.

It is while encountering new situations in life that the gender conflict comes into play highlighting the liminal space occupied by the female. Memories of her strong-willed mother flood Evaeverytime she feels depressed. The loss of her mother haunts her throughout her life, but she can feel her presence within her when she is targeted byan unjust society. Women, transexuals and the tribals occupy the periphery or the margins of existence. Eva helps the guerrillas in their impassioned struggle against the governmentforces due to her attachment to their leader and not out of her own political necessity. She holds neutral views regarding the political climate of the time but her proximity with bothHuberto and Rolf Carlé, enable her to know the real situation in both the fronts. She ispainfully aware of the degeneration that has occurred in the social systems whose agenda of manipulative domination perpetuates the oppressive machinery practised by the state. The government views the guerrillas as traitors whereas a constructive approach as to the circumstances behind their emergence would make things better for the nation.

Eva comprehends the bitter truth of gender disparity through her companionship withHuberto, who, despite being a guerrilla, is in reality, averse to the idea of according full freedom to women.

independent. Huberto

In his eyes, I would never be

had thought that way since he could

think at all; it

was not likely that the Revolution was

going to change

those attitudes. I realized that our problems were not

related in any way to the fortunes of the guerrillas;

Even if he achieved his dream, there

would be no

equality for me. For Naranjo, and others like him,

"the people" seemed to be composed exclusively

of men; we women should contribute to the struggle

but were excluded from decision-making and power.

Eva attempts to redefine the spaces that are traditionally allotted to women by subvertingthem and reconfiguring them in her own ways. Her mother instils in her daughter a love of stories and the will to persevere using her imagination in times of dire necessity. "Consuelo, my mother, spent her childhood in an enchanted region where for centuries

adventurers have searched for the city of pure gold the conquistadors saw when they peered into the abyss of their own ambitions. She was marked forever by that landscape, and in some way shemanaged to pass that sign on to me." (3)Greed and selfish motives undersore colonial intervention which throws into sharp focus the plight of the natives, the Indians who

occupy the margins and live in the jungle. Women and the natives suffer due to the unnatural influence wielded by the powerful. The natives are few in number and are separated from the rest of the nation. Their faces reflectcontentment in their limited spaces. In the large 
urban spaces, people fight each other for hegemony and authority. It is striking that Spanish

colonial rule has been unable to erase the traditional customs of the natives. "Those Indians, as poor as their ancestors at the beginnings of American history, had, even with the intrusion of colonizers, maintained their customs, language, and gods. Of the proud tribe of hunters

they once were, there remained only a few sad indigents, but the long record of misery had not erased the memory of their lost paradise, nor their faith in the legends that promised they would regain it. They were a smiling people." (246) The tribals are sidelined to such an extent that the government seems to be unaware of their existence. In the rush for

consolidating power, there occurs a segregation of the people, depending on their value that is estimated unjustly. Eva Lunarecords the fall of governments, with their failed systems, perennially unable to come up to the expectations of the citizens.

Carlés life runs parallel to the story of Eva and he has come to South America from Europe. He is a leading journalist who seeks to analyse the rationale behind theguerrilla uprising. Eva and Carlé end up helping nine guerrillas to escape from prison. Later it is known that the guerrillas have been defeated and that a truce is in the offing. It is acrucial situation that brings out the best in Eva as she finally thinks of settling in life. The relationships that Eva enter into express her desire to feel alive as a woman and

not as a means to flaunt her sexuality. She does not allow herself to be exploited, instead, she learns something from each experience. The female body is not a site of oppression and coercion. It does not follow that a woman's identity depends on how the male perceives her and that her thoughts and deeds should be concurrent with the norms laid down by society. Eva is able to create a space for herself not by languishing in the past but by coping with the changes in her circumstances. She feels hopeful about a future where she can be free in an emancipated environmentwithout being oppressed by the constraints of power, wealth, gender and society.

\section{CONCLUSION}

It can be understood that the source of a woman's creativity lies within herself. In the redefined spaces of her soul and body, her individuality progresses. Eva who has faced severe trials and tribulations in her eventful life emerges unscathed as a human being, keeping intact her innate goodness and compassion for others. In the novel, gender roles are challenged, specifically when Eva does things that are usually done by the male in accordance with the male/female binary. In the postcolonial situation the subversion of the assumed meaning of gender takes place leading to a negotiation of the fixity of gender roles.

The name Eva means "life," as she herself points out and she is able to continue her romance with life, not at the cost of others'happiness but by being true to herself. Arundhati Roy's exhortation for literary freedom for all artists in the present century in The Algebra of Infinite Justice is an eye-opener to all women who wish to expand their horizons. "If you limit the

trajectory of their flight, if you weigh their wings with society's existing notions of morality and responsibility, if you truss them up with preconceived values, you subvert theirendeavour." (191)

\section{REFERENCES}

[1] Allende, Isabel. Eva Luna. London: Penguin Books, 2009.

[2] Butler, Judith. Gender Trouble; Feminism and the Subversion of Identity. London: Routledge, 1990.

[3] Minh-ha, T. Trinh, Woman, Native, Other. USA: Indiana University Press, 1989.

[4] OyeronkeOyewumi. "Colonizing Bodies and Minds." In The Post-Colonial Studies Reader. London: Routledge, 2017.

[5] Roy, Arundhati. The Algebra of Infinite Justice. New Delhi: Penguin Books, 2001. 